\title{
Laparoscopic Testicular Artery Saving Varicocelectomy for Varicocele in Adolescents
}

\author{
EL-SAIED M. GHALWASH, M.Sc.; AHMED E. ABD ALLAH, M.D.; HESHAM F. ALI, M.D. and \\ MOHAMED M. SHALABY, M.D. \\ Pediatric Surgery Unit, General Surgery Department, Faculty of Medicine, Tanta University
}

\begin{abstract}
Background: Varicocele is generally considered to be the most common correctable cause of male infertility.

Testicular disproportion is considered to be the most important sign of testicular damage in absence of the possibility to do routine semen analysis in adolescent.

Aim of the Study: The aim of our work is to evaluate the feasibility, recurrence rate and postoperative complications of laparoscopic varicocelectomy with preservation of the testicular artery in adolescents.

Patients and Methods: Our prospective clinical study was done between May 2016 and May 2017 at pediatric surgery unit, General Surgery Department, Tanta University Hospital. The study included twenty patients presented with symptomatic varicocele. Then, laparoscopic varicocelectomy with preservation of the testicular artery were done for these cases. The operation time, the success rate, the incidence of complications, the length of the hospital stay and conversion to open varicocelectomy and data of follow-up were recorded.

Results: Total Operation time ranged between 10 and 40 minutes which was statistically significant in correlation with bilateral cases. There were testicular catch up growth in 5 cases and we had no testicular atrophy in the other cases Recurrence occurred in 2 cases in the period of follow-up ( 6 months).

Conclusions: Laparoscopic approach had advantages of minimal surgical trauma, lower morbidity and time sparing, faster recovery and better microscopic dissection with preservation of the spermatic artery.
\end{abstract}

Key Words: Laparoscopic - Varicocele - Varicocelectomy Adolescents - Testicular artery saving.

\section{Introduction}

VARICOCELE exerts a wide range of impact on seminal parameters ranging from none to absolute azoospermia with testicular atrophy. Their effect

Correspondence to: Dr. El-Saied M. Ghalwash, Pediatric Surgery Unit, General Surgery Department, Faculty of Medicine, Tanta University may be progressive as evidenced by the higher incidence of varicocele in (70 percent) in men with secondary infertility [1]. Indications for management of a varicocele Include: Pain, mass, psychic or cosmetic problems, subfertility or infertility, and affection in childhood or adolescents for fear of possible future testicular damage [2]. Laparoscopic varicocelectomy was introduced in the early1990s as an alternative to the Palomo's varicocelectomy [3]. Laparoscopic varicocelectomy gives the advantages of minimal surgical trauma, lower morbidity and time sparing, faster recovery, better microscopic dissection with preservation of the testicular artery along with amenable bilateral ligation without another incision [4].

\section{Patients and Methods}

Our prospective clinical study was done between May 2016 and May 2017 at pediatric surgery unit, General Surgery Department, Tanta University Hospital. The study included twenty patients presented with symptomatic varicocele. Any patients aged more than 19 years or any patients who have Secondary varicocele, cardiopulmonary co morbidity, hydrocele and recurrent cases; they were excluded from the study.

Preoperative assessment included: Complete blood count, liver function test, renal function test, coagulation profile, semen analysis if possible and imaging studies including Inguino scrotal $\mathrm{U} / \mathrm{S}$ with duplex study (it was done to confirm the diagnosis and detect grading of varicocele and other associated pathologies in the scrotum if present).

In supine position, Laparoscopic varicocelectomy typically involves 3 ports, The initial camera port was placed at the umbilicus and additional two ports were placed lateral to the recti muscles (Fig. 1). 
The posterior peritoneum was then grasped lateral to the testicular vessels and incised to form a window $2-3 \mathrm{~cm}$ away from deep inguinal ring. The vascular bundle was identified and isolated from the underlying psoas muscle and the testicular artery carefully identified. The group of structures that does not contain the artery was grasped with ipsilateral grasper then, separation of lymphatic vessels from the testicular vein was done (Fig. 2). The clip applier was inserted and then clips were applied to the proximal and the distal parts of the testicular vein (Fig. 3). The operator then inserted the scissors through the ipsilateral port and divide the veins between the clips (Fig. 4).

After securing homeostasis, Lastly, the clips were covered by peritoneum (Fig. 5).

Before removal of last port, the insufflation valve was opened and the carbon dioxied gas was expelled out from the peritoneal cavity. Wounds were closed with simple sutures.

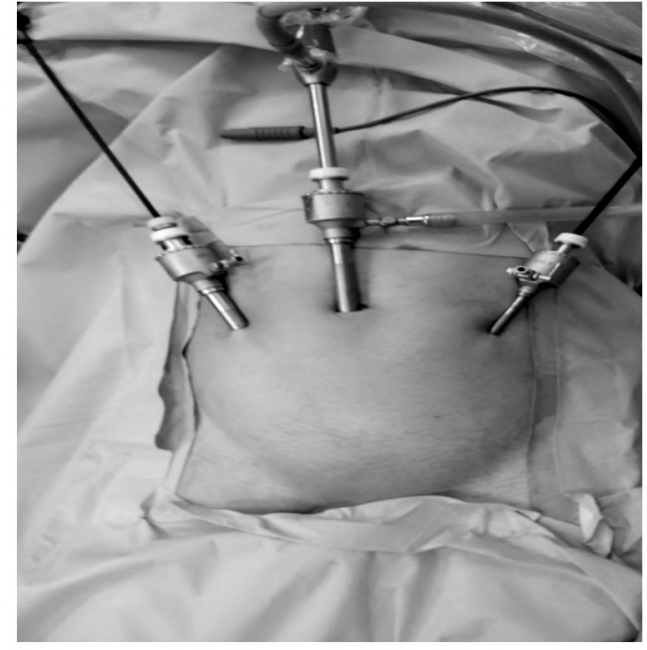

Fig. (1): Position of trocars.

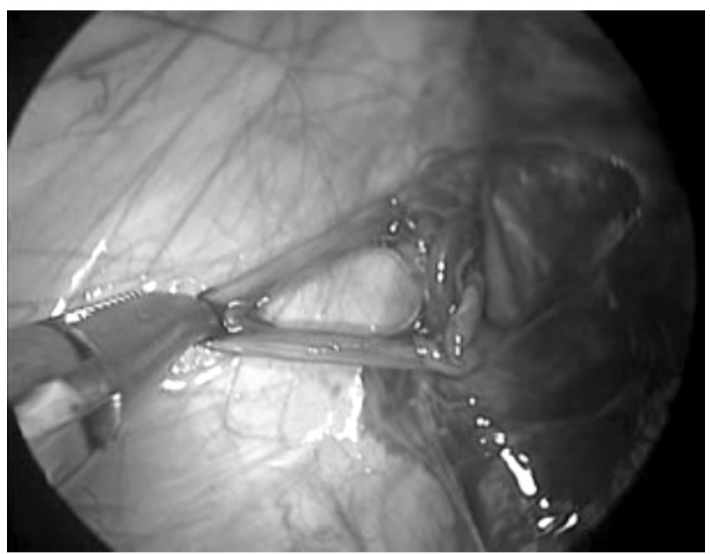

Fig. (2): Dissected testicular vein with preservation of lymphatics.

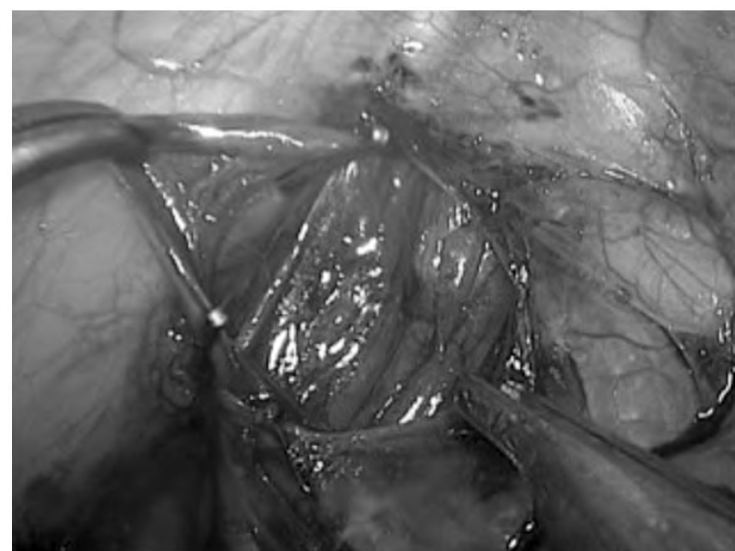

Fig. (3): Clips applied around spermatic vein.

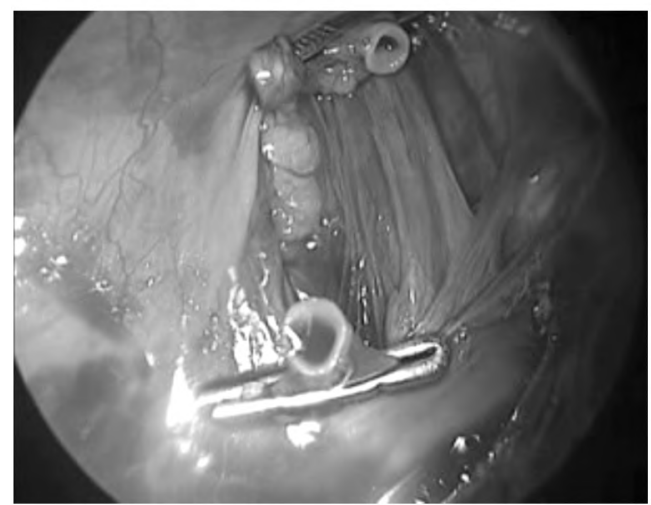

Fig. (4): Post cutting of segment of clipped vein.
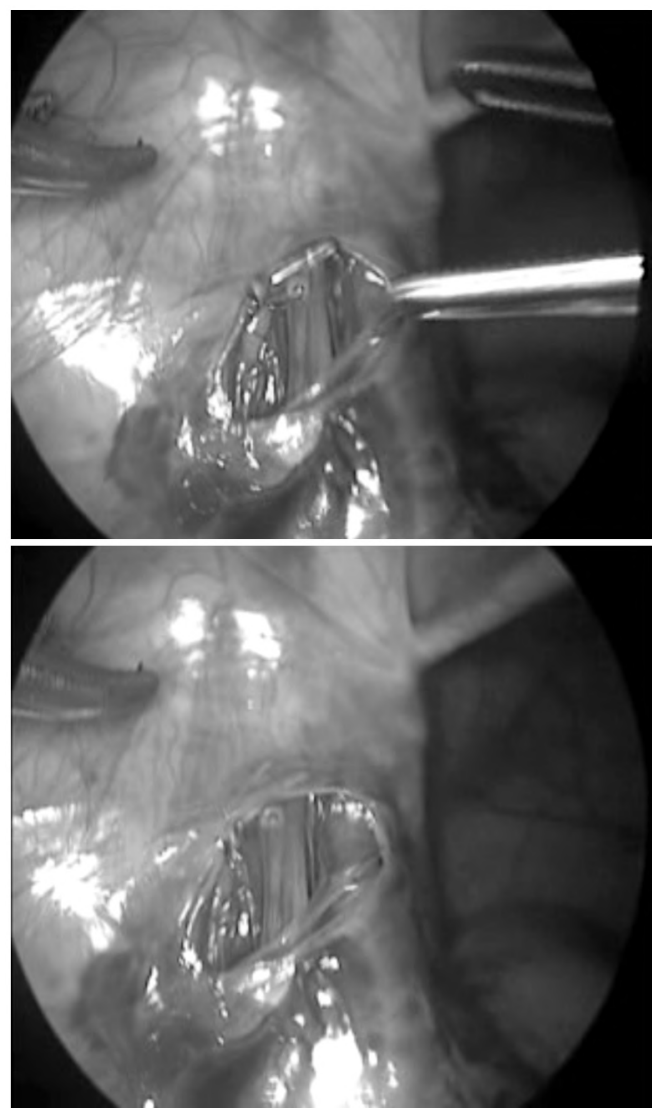

Fig. (5A-B): Covering of the clipped vein by peritoneum. 


\section{Results}

All (20) patients presented by scrotal pain and (5) patients, of them, were complaining of testicular disproportion in addition to pain (Table 1).

Bilateral varicocelectomy were done in 12 cases, and unilateral varicocelectomy was done in 8 cases. Operation time ranged between 25 and 50 minutes with mean time $33.65 \pm 10.39$ minutes. Only, one case was converted to open (sub inguinal approach) due to malfunction of the laparoscopic instruments (Table 2).

Table (1): Distribution of the studied cases according to symptoms $(n=20)$.

\begin{tabular}{lll}
\hline Symptoms & No. & $\%$ \\
\hline Pain & 20 & 100.0 \\
Testicular disproportion & 5 & 25.0 \\
\hline
\end{tabular}

Table (2): Distribution of the studied cases according to intra operative details $(\mathrm{n}=20)$.

\begin{tabular}{lll}
\hline Intra operative details & No. & $\%$ \\
\hline Varicocelectomy: & & \\
$\quad$ Unilateral & 8 & 40.0 \\
$\quad$ Bilateral & 12 & 60.0 \\
Operative time (min): & & \\
$\quad<30$ & 11 & 55.0 \\
$\geq 30$ & 9 & 45.0 \\
Bleeding: & & \\
$\quad$ No & 20 & 100.0 \\
$\quad$ Yes & 0 & 0.0 \\
Trauma: & & \\
$\quad$ No & 20 & 100.0 \\
$\quad$ Yes & 0 & 0.0 \\
Conversion: & & \\
$\quad$ No & 19 & 95.0 \\
$\quad$ Yes & 1 & 5.0 \\
\hline
\end{tabular}

Post-operative pain was variable 11 patients suffered from mild pain at port sites, 7 suffered from moderate pain also at port sites and 2 suffered from severe pain which was in the form of right shoulder pain, according to Verbal Pain Intensity scale (Fig. 6).

All patients were admitted in hospital for 24 hours except, one patient who was admitted for 48 hours was converted to open surgery. There was hydrocele formation in 2 cases only. Fig. (6): Distribution of the studied cases according to Pain.
Recurrence occurred in 2 cases in the period of follow-up ( 6 months). There were testicular catch up growth in 5 cases and we had no cases with testicular atrophy. Semen analysis done only in 18 patients and we found significant increase in spermatic count after surgery and also highly significant increase in motility of sperms after surgery (Table 3). Fig. (7) shows the disappearance of varicocele 3 months postoperative (Fig. 7).

Table (3): Comparison between spermatic count and motility pre and post-operative.

\begin{tabular}{ccc}
\hline $\begin{array}{c}\text { Before } \\
(\mathrm{n}=18)\end{array}$ & $\begin{array}{c}\text { After } \\
(\mathrm{n}=18)\end{array}$ & $\begin{array}{c}\text { Test of } \\
\text { sig. }\end{array}$ \\
\hline
\end{tabular}

Spermatic

count

(ml) $\left(x 10^{6}\right)$ :

$\begin{array}{lllll}\text { Min. - Max. } & 15.0-116.0 & 20.0-150.0 & Z= & 0.001^{*} \\ \text { Mean } \pm \text { SD. } & 44.67 \pm 32.25 & 56.44 \pm 32.13 & 3.378^{*} & \\ \text { Median } & 31.50 & 47.50 & & \end{array}$

Motility (\%):

Min. - Max. $20.0-65.0 \quad 35.0-66.0 \quad t=\quad<0.001 *$

Mean \pm SD $\quad 41.67 \pm 10.24 \quad 49.78 \pm 7.15 \quad 4.474 *$

$\begin{array}{lll}\text { Median } \quad 40.0 & 50.0\end{array}$

$\mathrm{Z}, p: \mathrm{Z}$ and $p$-values for Wilcoxon signed ranks test for comparing between before and after.

$t, p: t$ and $p$-values for Paired $t$-test for comparing between before and after.

*: Statistically significant at $p \leq 0.05$.

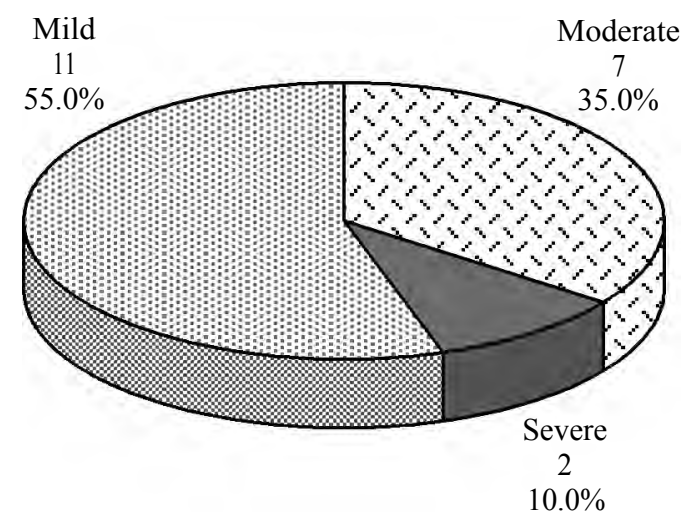




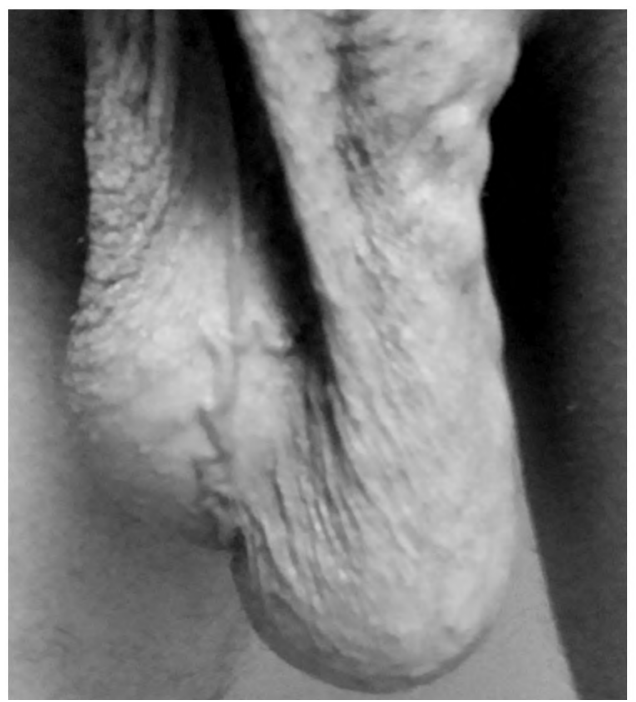

(A)

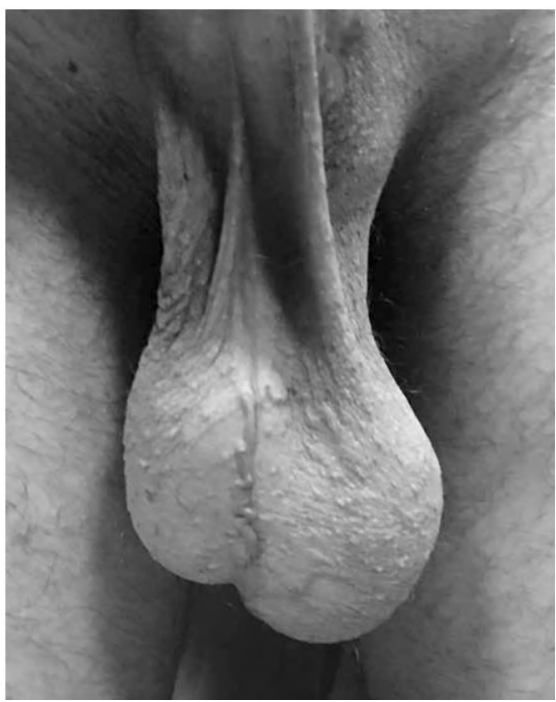

(B)

Fig. (7A-B): Follow-up after (3) months.

\section{Discussion}

An approach that enables intra-abdominal visualization of the testicular vessels is expected to reduce the rate of persistent or recurrent varicoceles [5]. Incidence of varicocele increases rapidly in the age group from 10 to 19 years to be $10-20 \%$ of adolescents, comparable with the incidence found in adults [6-9].

In this study, All patients presented by scrotal pain $(100 \%)$ and $5(25 \%)$ patients were complaining of testicular disproportion in addition to pain. There were visible dilated scrotal veins during scrotal skin examination in 13 patients and no visible veins found in 7 patients. There are varying opinions regarding correlation between grade of varicocele and degree of testicular hypotrophy in adolescents. Lyon et al., [10] found that no correlation of varicocele grade and testicular size in 30 adolescents. In contrast, Skoog et al., [11], Steeno et al., [12] and Paduch et al., [13] all independently noticed that boys with severe varicocele have a smaller ipsilateral testicle. Operation time was ranged between 25 and 50 minutes with mean time $33.65 \pm 10.39$ minutes. This was shorter time than that reported by Weimin Yu et al., [14], where the mean operation time was $40.2 \pm 8.3 \mathrm{~min}$ in their study. Regarding intra-operative complications, there was no intra operative bleeding. There was no intra operative damage to important structures. (e.g. great vessels, bowel, vas deferens). We converted only one case to open sub inguinal approach due to malfunction of the laparoscopic instruments.

In this study, Post-operative pain was variable. 11 patients suffered from mild pain, 7 suffered from moderate pain and 2 suffered from severe pain according to Verbal Pain Intensity scale. There were no wound infections.

There was hydrocele formation in 2 cases only. Weimin Yu et al., [14] reported in their work that, the incidence of hydrocele formation was similar between the two groups (artery preservation (AP) and artery ligation (AL) during laparoscopic varicocelectomy). None of the hydroceles, in this work, required intervention and all had disappeared by the 12 th month follow-up. The development of a hydrocele is associated most frequently with the Palomo procedure (total ligation) because no attempt is made to preserve the lymphatics [5].

Recurrence occurred in 2 cases in the period of follow-up (6 months). Weimin Yu et al., [14] reported in their work on 122 adolescents, there were 3 recurrences in patients in the AP group, and 2 recurrences in the AL group; there were no significant differences between the two groups.

There was no port site hernia during the period of follow-up. There was no testicular atrophy in all cases during the period of follow-up. Xiaokang Qi et al., [15] in their metaanlysis reported that, Postoperative atrophy may happen when the internal spermatic artery was ligated while the testicular collateral blood supply such as vassal and cremasteric arteries was very less or weak, but this condition was not very common.

There were testicular catch up growth in 5 cases and we had no testicular atrophy in the other cases. Weimin $\mathrm{Yu}$ et al., [14] reported in their work the catch-up growth rate was relatively low in the AL 
group at the 12 th month follow-up. The slow catchup growth in the AL group might correlate with the delayed restoration of the impaired vascular system. We found significant increase in spermatic count after surgery and also highly significant increase in motility of sperms after surgery. Because of restrictions based on age and legal reasons, semen analysis has not been used as a standard practice in adolescent varicocele patients; however, it is appropriate to carry out the analysis in older adolescents, when patient can give a specimen.

\section{Acknowledgments:}

This research was carried out without funding.

\section{Conflicts of interest:}

No conflicts of interest declared.

\section{Authors' contributions:}

All authors had equal role in design, work, statistical analysis and manuscript writing.

\section{References}

1- MORRIS P. and WOOD W.: Urology. In Oxford text book of surgery, volume 2, section 39. Edited by Morris P.J. and Malt R.A., 2nd edition, by Oxford Press, p. 209,2000.

2- SAYPOL D.C., HOWARDS S.S. and TURNER T.T.: Influence of surgically induced varicocele on testicular blood flow, temperature and histology in adult rats and dogs. Journal of Clinical Investigations, 68: 39-75, 1981.

3- FRANCO I.: Laparoscopic varicocelectomy in the adolescent male, current urology reproduction journal, 5 (2): 132-6, 2004.

4- COHEN R.: Laparoscopic varicocelectomy with preservation of the testicular artery in adolescents. Pediatric Surgery Journal, 36 (2): 394-6, 2001.
5- G.M.E. HUMPHREY and A.S. NAJMALDIN: Laparoscopy in the Management of Pediatric Varicoceles. Journal of pediatric surgery, Vol. 32: 1470-1472, 1997.

6- KUMANOV P., ROBEVA R.N. and TOMOVA A.: Adolescent varicocele: Who is at risk? Pediatrics, 121.1: e53e57, 2008

7- AKBAY E., CAYAN S., DORUK E., et al.: The prevalence of varicocele and varicocele-related testicular atrophy in Turkish children and adolescents. BJU Int., 3-86: 490 2000.

8- NIEDZIELSKI J., PADUCH D. and RACZYNSKI P. "Assessment of adolescent varicocele." Pediatric Surgery International, 12.5: 410-413, 1997.

9. OSTER J.: Varicocele in children and adolescents. An investigation of the incidence among Danish school children. Scand J. Urol. Nephrol., 5:27-32, 1971.

10- LYON, RICHARDS P., SUMNER MARSHALL, et al.: "Varicocele in childhood and adolescence: Implication in adulthood infertility?". Urology, 19.6: 641-644,1982.

11- COSTABILE R.A., SKOOG S. and RADOWICH M.: Testicular volume assessment in the adolescent with a varicocele. J. Urol., 147: 1348-1350, 1992.

12-STEENO O., KNOPS J., DECLERCK L., et al.: Prevention of fertility disorders by detection and treatment of varicocele at school and college age. Andrologia., 53- 8: 47, 1976.

13- PADUCH D.A. and NIEDZIELSKI J.: Repair versus observation in adolescent varicocele: A prospective study. J. Urol., 158: 1128-1132, 1997.

14- WEIMIN YU, TING RAO, YUAN RUAN, et al.: Laparoscopic Varicocelectomy in Adolescents: Artery-Ligation and Artery-Preservation. J. Urology, Volume 89, Pages 150-154, 2016.

15- XIAOKANG QI, KUNPENG WANG, GUANGCHEN ZHOU, et al.: "The role of testicular artery in laparoscopic varicocelectomy: A systematic review and meta-analysis". International Urology and Nephrology, 48.6: 955-965, 2016. 


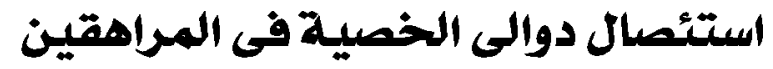 \\ بالمنظار الجراحى مع الحفاظ دوالم على شريان الحفين الخصية}

$$
\text { دوالى الخصية هى تمدد أوردة الخصية نتيجة الارتجاع الوديدى. }
$$

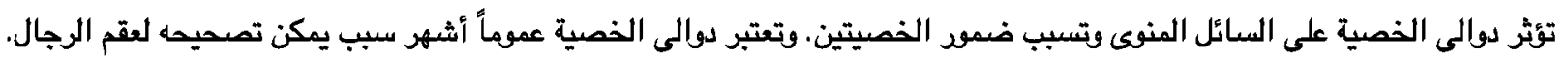

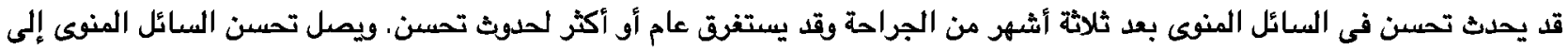

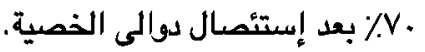

الربط الانتقائى للاوددة المتسعة مع الحفاظ على الشريان المنوى يقلل حدوث القيلة المائية فى معظم الأحيان لأنه يتم الحفاظ على الأوعية الليمفاوية.

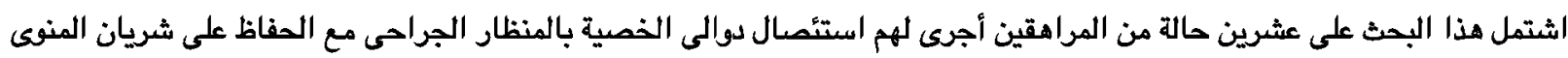

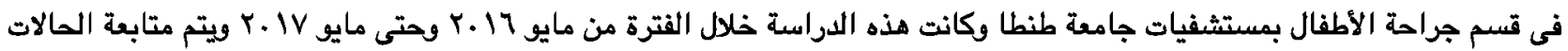

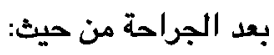

1- بابعة الجرح وتودم الخصيتين أو حدوث تجمع دموىى.

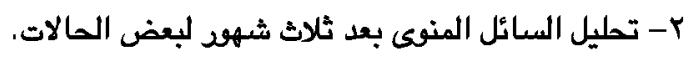

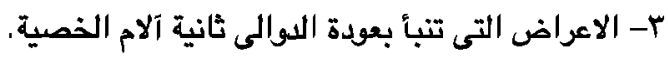
ع- عمل أشعة سونار على الخصيتين ودوبلكس لمتابعة حجم الخصيتين والدوالى المرتجعة. وقد أوضحت النتائج أن الحفاظ على الثريان المنوى أثناء عملية استئصسال دوالى الخصية يحسن من حجم الخصية فى المراهقين الذين

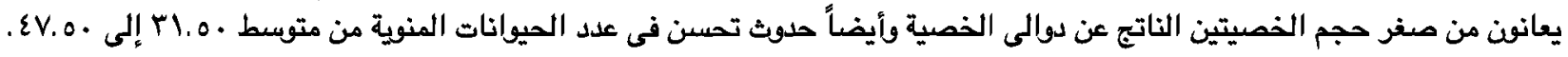

